\title{
AKTUALISASI HUKUM ISLAM DALAM UPAYA PELESTARIAN LINGKUNGAN HIDUP
}

\author{
Endang Widuri*
}

\begin{abstract}
Human beings have to preserve the nature and to avoid the environment damaging. To do that, there should be internalization on obeying laws. UU no 23 th. 1997 will only be a concept till Indonesia citizens are able to apply it daily as good Moslems and good citizens.
\end{abstract}

Kata kunci: Hukum Islam, pelestarian lingkungan bidup, UU Nomor 23 Tabun 1997 tentang Pengelolaan Lingkungan Hidup

\section{A. Pendahuluan}

Masalah lingkungan hidup merupakan masalah global yang dihadapi manusia dewasa ini. Kerusakan lingkungan hidup yang berupa pencemaran udara atau air, rusaknya lapisan ozon, erosi yang parah akibat penggundulan hutan dan sebagainya telah menyadarkan umat manusia atas tindakan-tindakan yang melampaui batas terhadap alam lingkungannya. Menyadari keadaan yang memprihatinkan tersebut muncullah gerakan-gerakan yang peduli terhadap pelestarian lingkungan hidup. Baik pemerintah, lembaga-lembaga swadaya masyarakat maupun rakyat secara individual telah ambil bagian untuk

'Penulis adalah Sarjana Hukum dan Magister Humaniora. Dosen Tetap Jurusan Syariah STAIN Purwokerto. 


\section{Endang Winduri}

menyelamatkan lingkungan.

Dalam bidang hukum telah dikeluarkan peraturan perundangundangan tentang lingkungan hidup, salah satunya adalah Undangundang Nomor 23 Tahun 1997 tentang Pengelolaan Lingkungan Hidup. Dengan dikeluarkannya peraturan perundang-undangan tersebut diharapkan penegakan hukum di bidang lingkungna dapat berdaya dan berhasil guna dan dalam jangka panjangnya pelestarian lingkungan hidup dapat tercapai. Di samping itu berbagai proyek pemerintah juga telah digalakkan dalam menanggulangi masalah kesehatan dan lingkungan hidup. Dengan banyaknya program dan dana yang telah diupayakan pemerintah tidak berarti secara otomatis masalah telah selesai. Upaya-upaya kesehatan dan lingkungan hidup tak ubahnya seperti ungkapan 'gali lubang tutup lubang'. Oleh karena itu, yang sangat penting adalah peningkatan kesadaran dan peran serta masyarakat dalam memelihara dan menanggulangi kondisi kehidupan lingkungannya. Dalam kaitan ini ajaran agama memegang peranan penting dalam menumbuhkan kesadaran para pemeluknya untuk melestarikan lingkungan hidup. Oleh karena itu, tulisan ini mencoba membahas aktualisasi hukum Islam dalam hubungannya dengan pelestarian lingkungan hidup.

\section{B. Kedudukan Manusia Sebagai Khalifah di Bumi dan Lingkungan Hidup}

Lingkungan hidup adalah kesatuan ruang dengan semua benda, daya, keadaan dan makhluk hidup, termasuk di dalamya manusia dan perilakunya yang mempengaruhi kelangsungan perikehidupan dan kesejahteraan manusia serta makhluk hidup lainnya. Keberagaman unsur lingkungan hidup membentuk sebuah hubungan tarik menarik antara komponen yang satu dengan komponen yang lainnya. Apabila dalam hubungan tersebut salah satu kelompok melakukan eksploitasi yang berlebihan, maka kerusakan akan terjadi di fihak lain yang, disadari atau tidak, berarti kerusakan bagi kelompoknya juga.

Eksploitasi hanya bisa terjadi jika terdapat interaksi antara unsur-unsur lingkungan hidup yang ada dan membentuk suatu 78

Al Manāhij, Vol. 2 No. 1 Januari - Juni 2008 
kumpulan yang biasa disebut komunitas biotik (makhluk hidup). Selain itu di dalam komunitas tersebut terdapat pula zat-zat yang tidak memilki sifat-sifat kehidupan (komunitas abiotik) yang diperlukan oleh makhluk hidup, seperti air; tanah; garam; udara; cahaya dan sebagainya. Kedua unsur makhluk tersebut berada dalam satu sistem ketergantungan baik secara struktural maupun fungsional.

Permasalahan lingkungan hidup bukanlah permasalahan baru, permasalahan itu ada sejak bumi diciptakan. ${ }^{1}$ Pada mulanya permasalahan lingkungan hidup lebih banyak disebabkan oleh faktor lingkungan itu sendiri dan bencana alam. Ketika manusia muncul sebagai suatu komunitas dalam alam raya, maka manusialah yang memegang dominasi kerusakan lingkungan hidup.

Manusia menyemarakkan dunia industri. Pencemaran lingkungan akibat limbah industri menjadi persoalan pokok bagi negara-negara maju, sedangkan bagi negara berkembang seperti Indonesia, umumnya kerusakan lingkungan paling banyak disebabkan oleh limbah individu/rumah tangga. Akan tetapi, pada umunya pencemaran oleh industri mendapat perhatian lebih besar daripada pencemaran yang disebabkan oleh limbah rumah tangga. Pada akhirnya anggapan orang terarah pada teknologi adalah biang kerok kerusakan lingkungan hidup. ${ }^{2}$

Anggapan seperti tersebut di atas tentu saja tidak sepenuhnya benar, karena teknologi di samping dapat merusak lingkungan hidup, juga diperlukan untuk mengatasi masalah lingkungan hidup. Manusia primitif membawa barang dengan cara memikul. Zaman sekarang memikul (metabolisme intern) diganti dengan menggunakan BBM (metabolisme elestern), karena cara memikul dengan memanfaatkan metabolisme intern secara berlebihan dianggap tidak manusiawi. Hidup sederhana bukan berarti menolak penggunaan sumber daya ekstern yang lebih banyak asalkan dilakukan secara efisien dan untuk maksud produktif. ${ }^{3}$

\footnotetext{
${ }^{1}$ Nogarsyah Moede, Bagaimana Menjaga Kelestarian Lingkungan Hidup Menurut Agama Islam (Bandung: Marjan, 1993), hal. 16.

${ }^{2}$ Ibid., hal. 17.

${ }^{3}$ Otto Soemarwoto, Ekologi Lingleungan Hidup dan Pembangunan (Bandung: Djambatan, 1991), hal. 173.
}

Al Manāhij, Vol. 2 No. 1 Januari - Juni 2008 


\section{Endang Winduri}

Adanya amanat yang dibebankan kepada manusia untuk memakmurkan bumi membawa konsekuensi bahwa menyia-nyiakan kewajiban mengolah alam untuk kepentingan manusia akan tergolong mengabaikan amanat yang diberikan Allah kepada manusia. Walaupun demikian, dalam memanfaatkan kekayaan alam, manusia tidak boleh melaksanakannya secara berlebih-lebihan mengingat potensi alam yang terbatas, sehingga kelestariannya perlu dipupuk untuk dapat dimanfaatkan sepanjang mungkin umur kemanusiaan. ${ }^{4}$

Banyak fakta menunjukkan, bahwa mengeksploitasi alam secara berlebihan membawa dampak yang merugikan bagi manusia itu sendiri. Misalnya, penebangan hutan secara liar (pembalakan hutan) tanpa diimbangi dengan usaha penghijauan kembali, telah membawa akibat buruk terjadinya erosi dan penggurunan; eksploitasi kekayaan laut seperti ikan dengan cara-cara yang ceroboh telah memusnahkan beberapa spesies di laut; penggalian pasir secara berlebih-lebihan telah menimbulkan kerusakan alam yang cukup parah dan sebagainya. Selain itu, masalah lingkungan hidup di Indonesia saat ini adalah polusi air dari limbah industri dan pertambangan; polusi udara di daerah perkotaan; asap dan kabut dari kebakaran hutan; kebakaran hutan permanen/tidak dapat dipadamkan; perambahan suaka alam/suaka margasatwa; perburuan liar, perdagangan dan pembasmian hewan liar yang dilindungi; penghancuran terumbu karang; pembuangan sampah B3/ radioaktif dari negara maju; pembuangan sampah tanpa pemisahan/ pengolahan; dan semburan lumpur liar di Sidoarjo Jawa Timur.

Fakta-fakta tersebut sejalan dengan apa yang telah difirmankan Allah dalam al-Qur'an surah ar-Rum ayat 41 yang menyatakan:

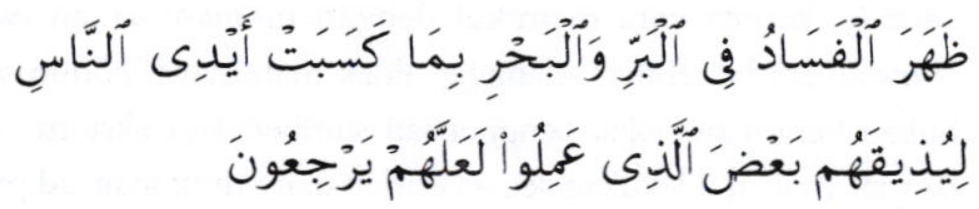

${ }^{4}$ Ahmad Azhar Basyir, Citra Manusia Muslim (Yogyakarta: Fakultas Hukum Universitas Islam Indonesia, 1991), hai. 15. 
Ayat tersebut menjelaskan bahwa kerusakan-kerusakan yang terjadi di bumi, baik di daratan maupun di lautan karena tangantangan manusia itu sendiri. Padahal diciptakannya manusia itu bukan untuk mengadakan kerusakan-kerusakan, melainkan agar menjadi khalifah di bumi dan untuk berbakti kepada Allah.

Manusia yang diserahi Allah sebagai khalifah fi al-ard memikul tanggung jawab yang tidak ringan berkaitan dengan alam semesta ini, sebab khalifah di muka bumi dapat diartikan sebagai pemegang kekuasaan atau amanat untuk mengatur dan mengelola alam seisinya. Hal ini merupakan amanat yang telah dipikulkan Allah kepada manusia, sebab manusia itu sendiri yang telah berjanji kepada Allah untuk memikul amanat tersebut, sebagaimana disebutkan dalam AlQur'an surah al-Ahzab ayat 72 sebagai berikut:

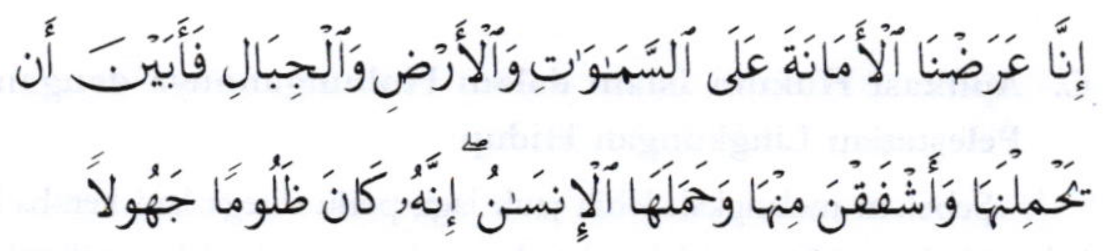

Sebagian musafir mengartikan amanat dalam konteks ayat di atas adalah alam semesta beserta segala isi dan hubungan keseimbangan yang terdapat di dalamnya. Apabila diambil pengertian yang demikian itu, berarti kelahiran manusia di bumi ini adalah untuk memenuhi amanat Allah. Dalam rangkaian surat-surat yang terdapat di dalam al-Qur'an tersimpul, bahwa amanat tersebut mencakup kewajiban dan tanggung jawab manusia kepada Aliah, tanggung jawab manusia pada diri sendiri, tanggung jawab manusia sesamanya, dan tanggung jawab manusia dengan lingkungan hidupnya. ${ }^{5}$

Disamping itu, ayat tersebut menganjurkan agar manusia belajar dari sejarah, membaca dan mempelajari perbuatan dan perilaku orang-orang dahulu, sehingga dapat mengetahui apa akibatnya jika menebang hutan seenaknya, apa akibatnya membuang limbah di sungai, sehingga dengan demikian manusia dapat menahan diri untuk tidak

${ }^{5}$ Moede, Bagaimana Menjaga Kelestarian, hal. 29. 


\section{Endang Winduri}

melakukan perbuatan yang dapat menimbulkan kerugian pada manusia itu sendiri. Selama mereka taat, dengan memelihara diri dan lingkungannya dari sebab-sebab kerusakan, maka mereka akan terjaga dari segala bencana, baik di daratan maupun di lautan.

Konsep alam dan hukum yang terkandung di dalamnya, termasuk keseimbangan ekosistem sebagai amanat Allah menjadi penting untuk dikaji, lebih-lebih apabila dihubungkan dengan pengertian hukum Islam yang mencakup seluruh konsep keseimbangan, proses penciptaan, upaya mempertahankan eksistensi ciptaan, tujuan penciptaan, dan akhir penciptaan. Dengan istilah lain hukum Islam yang selama ini hanya difahami mengatur hubungan manusia dengan Tuhan dan manusia dengan manusia akan ditambah dengan hubungan manusia dengan alam.

\section{Aplikasi Hukum Islam dalam Hubungannnya dengan Pelestarian Lingkungan Hidup}

Sebelum melangkah lebih jauh lagi, perlu ditegaskan kembali bahwa hukum Islam adalah seluruh aspek yang ada dalam seluruh tata tertib pada setiap masyarakat (benda mati, tumbuhan, hewan, manusia, dan jagat raya). Hukum Islam dikatakan menyangkut seluruh aspek yang maujud didasarkan pada asumsi, bahwa keseimbangan yang ada di seluruh alam adalah tata tertib hukum Allah (sunnatullah) yang wajib diyakini kebenarannya.

Dengan dasar pengertian di atas, sunnatullah menjadi penting untuk ditelaah, bagaimana bentuk keseimbangan itu, bagaimana hubungan yang dapat menjadi keseimbangan. Mempelajari sunnatullah tidak ada beda pentingnya dengan mempelajari hukum, karena sunnatullah sendiri adalah hukum. Akan tetapi, manusia bagaimanapun tetap dibatasi oleh sifat insaniyyah-nya, sehingga banyak hal yang terkait dengan sunnatullah tidak mampu ditelaah, akhirnya ada sunnatullah yang tetap menjadi misteri sampai hari kiamat.

Dengan banyaknya sumber daya alam seperti kayu, batu bara, minyak bumi, dan sebagainya yang dijadikan energi, suhu bumi naik 
dan hal ini dapat mengakibatkan naiknya permukaan air laut, terutama daerah-daerah dekat kutub. Suhu bumi akan kembali menurun jika terjadi ledakan gunung berapi. Kejadian alam seperti itu adalah salah satu contoh tata keseimbangan yang telah ditetapkan oleh Allah. Seorang muslim yang meyakini kebenaran Islam perlu menyadari adanya ketentuan Allah yang berada di luar diri manusia, sehingga kewajiban sebagai muslim tidak terbatas hanya pada pelayanan terhadap diri sendiri secara internal, akan tetapi harus pula memperhatikan lingkungan hidup di luar dirinya.

Persoalannya kemudian, tidak setiap muslim tahu arti penting mengimani tata hukum Allah di luar tata hukum yang berlaku pada masyarakat manusia. Kalaupun ada yang tahu, tidak banyak yang mau mengaktualisasikan pengetahuannya tersebut dalam bentuk tindakan nyata. ${ }^{6}$ Oleh karena itu tidak mengherankan jika Allah menyindir manusia melalui firman-Nya dalam surah ar-Rum ayat 41:

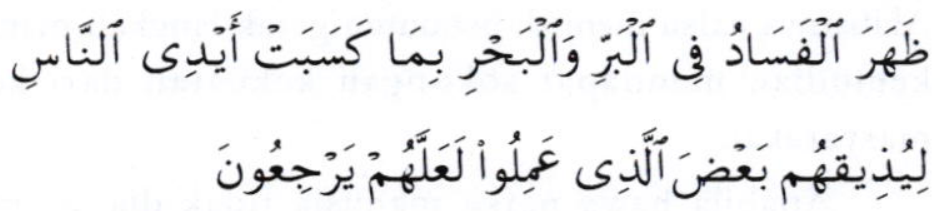

Di balik kerusakan di darat dan di laut, baik yang disebabkan oleh ketidakpatuhan manusia maupun karena kemusyrikan dan maksiat terhadap aturan dan hukum Allah. Sebenarnya Allah telah membuat aturan yang harus dijalankan oleh setiap muslim. Aturan itu adalah hukum Islam yang bertujuan mewujudkan kemaslahatan hidup manusia, baik jasmani maupun rohani, individu dan sosial. Kemaslahatan itu bukan hanya untuk kehidupan dunia, tetapi juga untuk kehidupan kekal di akherat. ${ }^{7}$

Agar tujuan tersebut dapat tercapai, tentunya manusia harus mematuhi peraturan-peraturan yang telah ditentukan oleh hukum tersebut. Kepatuhan seseorang terhadap hukum dipengaruhi oleh dua faktor, yaitu:

\footnotetext{
${ }^{6}$ Asri Rasad, Islam Untuk Disiplin Ilmu Biologi (Jakarta, 1995), hal. 23.

${ }^{7}$ Mohamad Daud Ali, Hukum Islam Pengantar Ilmu Hukum dan tata Hukum Islam di I(ndonesia Jakarta: Rajawali Press, 1996), hal. 53.
}

Al Manāhij, Vol. 2 No. 1 Januari - Juni 2008 


\section{Endang Winduri}

\section{Faktor Internal}

Faktor internal adalah faktor yang mempengaruhi kepatuhan seseorang terhadap hukum, yaitu jiwa orang itu sendiri. Hukum tidak mengatur perbuatan orang secara batin/jiwa dan fikiran, hukum hanya mengatur perbuatan secara lahir saja, akan tetapi al-Qur'an mengatur perkembangan jiwa manusia, sehingga al-Qur'an memberikan dasar supaya hukum dipatuhi oleh manusia berdasarkan kesadaran hukum dalam jiwanya.

Kesan yang timbul selama ini adalah bahwa ilmu hukum sepertinya membiarkan saja jiwa manusia berkembang tanpa bimbingan. Akan tetapi pada saat yang sama ia menuntut agar jiwa manusia memiliki kesadaran untuk mematuhi hukum. Mungkin kesan itu akibat renaissance yang membuat manusia mabuk oleh kemerdekaan formil, sehingga manusia berbuat dalam masyarakat dengan kebebasan penuh, tidak perlu diatur. Akibatnya nafsu menjadi penuntun gerak langkah manusia yang kemudian mendapat sokongan kekuatan dari kekuasaan masyarakat.

Apabila hawa nafsu manusia tidak diatur, maka yang timbul adalah kesewenang-wenangan, dimana yang kuat menindas yang lemah. Akibatnya kesejahteraan tidak akan terwujud. Oleh karena itu, harus ada peraturan yang membimbing hawa nafsu seseorang ke arah perkembangan yang positif, sehingga manusia yang mempunyai jiwa tidak lagi menindas pihak yang lemah hanya untuk memuaskan hawa nafsunya. Artinya penanaman pada jiwa tentang kesadaran mematuhi hukum harus didahulukan sebelum dikenalkan pada hukum itu sendiri.

\section{Faktor Eksternal}

Hukum sebagai penyebab kepatuhan eksternal harus disosialisasikan ke dalam jiwa manusia, sehingga pertemuan dua unsur kepatuhan hukum dapat melahirkan tindakan yang sesuai dengan kehendak hukum. Pelanggran hukum akan berakibat pada sanksi di mana setiap orang berusaha untuk menghindarinya. 
Dalam kaitannya dengan kepatuhan manusia terhadap ajaran Islam yang berkenaan dengan lingkungan hidup ada dua predikat yang diberikan Allah kepada manusia. Pertama, manusia sebagai khalifah di muka bumi, ${ }^{8}$ yang bertugas menjalankan amanat Allah dalam segala aspek kehidupan. ${ }^{9}$ Kedua, manusia sebagai perusak lingkungan hidupnya, ${ }^{10}$ yang menjadi penyebab terjadinya kerusakan di daratan dan di lautan.

Dalam keadaan yang demikian manusia berada pada posisi yang dilematis, di satu sisi ia memiliki potensi untuk mengemban amanat yang tidak ringan sebagai khalifah di bumi, sementara pada sisi yang lain manusia juga memiliki potensi untuk menjadi perusak lingkungan hidupnya. Akan tetapi justru inilah kelebihan yang diberikan pada manusia di banding makhluk Allah lainnya. Manusia dijadikan lebih mulia daripada makhluk lainnya, karena ia diberi akal dan nafsu oleh Allah agar dapat dinilai amal perbuatan hamba-Nya. Penilaian ini didasarkan atas kadar usahanya, bukan pada pada hasil yang dicapai dari usaha itu. Nabi Ibrahim, misalnya, kendati pengikutnya lebih sedikit dibandingkan Nabi Sulaiman, namun ia mendapatkan gelar ulu al'azm bersama Nabi Nuh, Nabi Musa, Nabi Isa, dan Nabi Muhammad; sementara Nabi Sulaiman justru tidak termasuk dalam kategori itu.

\section{Peraturan Pengelolaan Lingkungan Hidup di Indonesia}

Dewasa ini banyak terjadi eksploitasi sumber daya alam secara besar-besaran yang cenderung mengesampingkan dampak negatif bagi keseimbangan ekosistem dan pelestarian lingkungan hidup. Kenyataan ini membuat pemerintah Indonesia merasa perlu menerbitkan Undang-Undang Tentang Pengelolaan Lingkungan Hidup, yakni Undang-undang Nomor 23 Tahun 1997. Undangundang ini merupakan pengganti bagi undang-undang sebelumnya, yakni Undang-Undang Nomor 4 Tahun 1982.

\footnotetext{
${ }^{8}$ Q.S. al-An'am: 65.

${ }^{9}$ Q.S. al-Ahzab: 72

${ }^{10}$ Q.S. ar-Rum: 41.
} 


\section{Endang Winduri}

Dalam Undang-undang Nomor 23 Tahun 1997 poin menimbang pada huruf (b) disebutkan:

Bahwa dalam rangka mendayagunakan sumber daya alam untuk memajukan kesejahteraan umum seperti diamanatkan dalam UUD 1945 dan untuk mencapai kebahagiaan hidup berdasarkan Pancasila, perlu dilaksanakan pembangunan berkelanjutan yang berwawasan lingkungan berdasarkan kebijaksanaan nasional yang terpadu dan menyeluruh dengan memperhitungkan kebutuhan generasi masa kini dan generasi masa depan. ${ }^{11}$

Pertimbangan di atas menunjukkan perlunya pengelolaan lingkungan hidup secara efisien, berdaya guna, dan berhasil guna dengan tetap memperhatikan kelangsungan keseimbangan ekosistem.

Dengan dikleluarkannya undang-undang tersebut diharapkan tanah air Indonesia yang selalu disebut sebagai jamrud katulistiwa akan benar-benar menjadi kenyataan. Melestarikan lingkungan hidup merupakan perbuatan mulia yang sangat dianjurkan dalam al-Qur'an dan hadis.

Baik dalam ayat al-Qur'an maupun hadis Nabi, secara tegas dinyatakan bahwa perbuatan yang bersifat merusak atau mencemarkan lingkungan adalah termasuk perbuatan yang dilarang. Akan tetapi kedua sumber primer hukum Islam tersebut tidak menyebutkan sanksi apa yang mesti dijatuhkan kepada pihak-pihak yang melanggar larangan tersebut. Oleh karena itu penguasa (dalam hal ini adalah eksekutif dan legislatif) memiliki kewenangan untuk menetapkan sanksi seperti apa yang akan dikenakan kepada pihak-pihak yang melakukan pelanggaran. Dalam konteks inilah pemerintah bersama dengan lembaga legislatif menetapkan sanksi pidana, baik berupa hukuman badan maupun denda, kepada pihak-pihak yang melakukan perusakan atau pencemaran lingkungan.

${ }^{11}$ UU No. 23 Tahun 1997 Tentang Pengelolaan Lingkungan Hidup. 
Dengan ditetapkannya sanksi pidana tersebut diharapkan anggota masyarakat yang memiliki kecenderungan merusak lingkungan hidup akan berpikir dua kali untuk mewujudkan niatnya. Dengan begitu lingkungan hidup menjadi terjaga kelestariannya. Dengan terpeliharanya kelestarian lingkungan hidup, akan terciptalah lingkungan yang sehat bagi kehidupan manusia.

\section{E. Kesimpulan}

Hukum Islam bukanlah hukum yang sempit seperti yang difahami banyak orang selama ini, yang hanya mengatur manusia. Hukum Islam mencakup segala aspek yang maujud dengan segala keseimbangan yang ada. Umat Islam secara dengan sendirinya berkewajiban menjalankan ajaran-ajaran hukumnya sebagai konsekuensi keislamannya. Dengan menjalankan ajaran hukum Islam secara benar niscaya akan tercipta keseimbangan dan keharmonisan hubungan antara sesama manusia dan lingkungan alamnya.

Islam sangat peduli terhadap upaya pelestarian lingkungan hidup dan mengutuk segala bentuk tindakan yang berakibat pada kerusakan lingkungan. Alam semesta ini diciptakan oleh Allah untuk manusia sebagaimana tercantum dalam Q.S. al-Baqarah ayat 29 yang menyatakan "Dia-lah Allah yang menjadikan segala yang ada di bumi untukmu". Oleh karena itu manusia wajib memelihara kelestariannya dan tidak boleh merusaknya seperti disebutkan dalam Q.S. AlQashash ayat 77 "Dan janganlah kamu berbuat kerusakan di muka bumi. Sesungguhnya Allah tidak menyukai orang-orang yang berbuat kerusakan.” 


\section{DAFTAR PUSTAKA}

Ali, Daud, Mohammad. Hukum Islam Pengantar Ilmu Hukum dan tata Hukum Islam di Indonesia. Jakarta: Rajawali Press, 1996.

Basyir, Ahmad Azhar. Citra Manusia Muslim. Yogyakarta: Fakultas Hukum Universitas Islam Indonesia, 1991.

Moede, Nogarsyah. Bagaimana Menjaga Kelestarian Lingkungan Hidup Menurut Agama Islam. Bandung: Marjan, 1993.

Rasad, Asri. Islam Untuk Disiplin Ilmu Biologi. Jakarta, 1995.

Soemarwoto, Otto. Ekologi Lingkungan Hidup dan Pembangunan. Bandung: Djambatan, 1991.

UU No. 23 Tabun 1997 Tentang Pengelolaan Lingkungan Hidup. 